\title{
THE EFFECT OF CORPORATE DIVERSIFICATION, CUSTOMER CONCENTRATION ON TAX AVOIDANCE IN INDONESIA
}

\author{
PUTRA ARYOTAMA \\ AMRIE FIRMANSYAH (amrie.firmansyah@gmail.com)
}

Department of Accounting, Polytechnic of State Finance STAN, Indonesia

\begin{abstract}
A B S T R A C T
This study aims to examine the effect of corporate diversification, customer concentration on tax avoidance in Indonesian Non-Financial Companies. Companies diversify because of the private benefits managers receive from diversifying. Also, companies may choose to have only a few customers to create a close relationship with those customers. Meanwhile, tax avoidance is a reduction in corporate tax liability, which is conducted by the company legally. This study employs a quantitative method using linear regression analysis and uses panel data of companies listed under the Indonesian Non-Financial Companies on IDX from 2014 to 2017. Based on purposive sampling was conducted, the total number of observations is 483 firm-year. The results of this study suggest that corporate diversification and customer concentration are positively associated with tax avoidance.
\end{abstract}

Keywords: Diversification, Concentration, Non-Financial Companies, Tax Avoidance

\begin{abstract}
Penelitian ini bertujuan untuk menguji pengaruh diversifikasi perusahaan, konsentrasi pelanggan terhadap penghindaran pajak di Perusahaan Non-Keuangan Indonesia. Perusahaan melakukan diversifikasi dalam operasinya untuk mengejar keuntungan pribadi manajer dari aktivitas tersebut. Selain itu, perusahaan dapat memilih untuk memiliki hanya beberapa pelanggan untuk membuat hubungan yang erat dengan pelanggan tersebut. Sementara itu, penghindaran pajak adalah pengurangan kewajiban pajak perusahaan, yang dilakukan oleh perusahaan secara legal. Penelitian ini menggunakan metode kuantitatif dengan menggunakan analisis regresi linier. Data yang digunakan dalam penelitian ini adalah data laporan keuangan Perusahaan Non-Keuangan Indonesia di BEI dari 2014 hingga 2017 sesuai dengan data panel. Berdasarkan purposive sampling yang telah dilakukan, jumlah sampel dalam penelitian ini adalah 483 observasi (firm-year). Hasil penelitian ini menunjukkan bahwa diversifikasi perusahaan dan konsentrasi pelanggan berpengaruh positif terhadap penghindaran pajak.

Kata kunci : Diversifikasi, Konsentrasi, Perusahaan Non-Keuangan, Penghindaran Pajak
\end{abstract}

\section{INTRODUCTION}

The international scandals such as the infamous Panama Papers or Google's Double Irish with a Dutch Sandwich scheme brought light to the public on how far corporations go to avoid paying taxes (History.com Editors, 2009). In Indonesia, an example of a case of tax avoidance is between the government and Alphabet Inc's Google Asia Pacific. In June 2017, the company agreed on an undisclosed tax payment after a long dispute with the government caused by a loophole in the domestic tax system. Indonesia's Finance Minister added that "aggressive tax planning is part of a company's core business" (Reuters, 2017).
For governments, the revenue from taxation is needed to pay for the many functions of government: remedies externalities, provides public goods (such as infrastructure and education), regulation, and many others to improve the economic well-being of its people (Mankiw, 2012). For businesses and corporations, however, that is not the case. Tax, for them, is another cost that is being imposed by law. Businesses also bore extra costs to administer these taxes. It erodes business profits and disincentivizes their economic activity. Businesses will try and pass that extra cost on consumers. It creates a deadweight loss in an already efficient economy (Mankiw, 2012). It distorts the price and allocation of 
goods and services in the economy.

Because of this tug of interest, governments will always try to enforce tax regulation for more revenue and compliance from businesses. Businesses, on the other hand, always try to exploit loopholes in the regulation to try and minimize or even avoid paying taxes. This act by businesses to minimize or avoid paying tax can be classified as tax avoidance or tax evasion. Kirchler (2007) distinguishes the difference as through legal means (tax avoidance) or illegal means (tax evasion). By legal means, firms try to exploit the loopholes that exist in the tax regulation to minimize or avoid paying taxes. Otherwise, by illegal means, companies blatantly disregard the tax regulation and unlawfully avoids paying taxes altogether. Guenther, Matsunaga, \& Williams (2017) went even further by distinguishing legal tax planning based on the fact whether management deemed it would likely be overturned by the tax authority (tax aggressiveness) or not (tax avoidance).

Tax evasion has a fundamental difficulty in that it is empirically tough to measure because of the lack of information on taxpayer compliance, the measurement of which is beyond the analysis of a typical financial statement of positive accounting research (Alm, 2012). Based on that reasoning, for this research, tax avoidance is defined as a means by which the management of corporations can reduce, minimize, or even avoid paying taxes by legal means. One way a company's tax avoidance level can be analyzed is through its accounting information.

According to a research by Cobham \& Janský (2018), the annual global revenue loss from corporate tax avoidance amounts to US\$ 500 billion with the highest intensity of losses occurring in low-income and lower-middle-income countries and across sub-Saharan Africa, Latin America, and the Caribbean and South Asia. Indonesia (a lower-middle-income country) itself is estimated to lose around US\$ 6.48 billion (equals to $\mathrm{Rp} 91.8$ trillion) annually from corporate tax avoidance. In the South-East Asia region, the amount of annual loss in Indonesia is the biggest among its peers. The Philippines came in a close second. In contrast to Indonesia, Malaysia, the Philippines, and Myanmar, the countries of Singapore, Thailand, and Cambodia gain a net benefit from corporate tax avoidance. Corporations tend to shift their income to those countries to attain lower tax rates or several tax benefits.

They are usually risk-averse and operate on proven stable lines of product. On the product side, this study looks at how diversified the business is, how many segments the business is involved in. On the customer side, this study looks at the customer base and customer relationship. The customer base is related to how concentrated or diversified its customers are. Concentrated customer means that most of the firm's revenue comes from a small number of customers (Marvin, 2019). Another aspect of the customer side is the relationship between the company and its customers. Companies can either sell their products to related parties or other customers, which is unrelated to the company. Thus, the study is aimed to examine corporate diversification and customer concentration on tax avoidance.

Although studies have been conducted individually about the effect of business diversification and customer concentration on tax avoidance (Arieftiara, Utama \& Wardhani, 2015; Wardani \& Khoiriyah, 2018; Zheng, 2017; Huang, Sun \& Zhang, 2017; Oktavia, Kristanto, Subagyo \& Kurniawati, 2012; Azizah \& Kusmuriyanto, 2016; Sari, Utama \& Rossieta, 2017), this study differs from the previous study because this study is the first study to incorporate all these business decisions and investigates its relation on tax avoidance in the Indonesian context. Moreover, customer concentration and corporate diversification have not been previously studied in Indonesia as well as this research is the first to do so.

To control for extraneous effect, this research also employs several control variables. These control variables are variables that have been proven to relate to tax avoidance based on previous studies. Those control variables are profitability (Dewi \& Noviari, 2017; Arianandini \& Ramantha,2018; Darmawan \& Sukartha, 2014, 
leverage (Lestari \& Putri, 2017; Dewi \& Noviari, 2017) and size (Darmawan \& Sukartha, 2014; Wijayanti, Wijayanti \& Chomsatu, 2017; Dewi \& Noviari, 2017).

One of the most notable theories on a positive accounting framework was put out by Watts and Zimmerman (1986): the political-cost hypothesis. According to the political cost hypothesis, the higher the political cost to the company, the more likely it is for the management to defer reported earnings from current periods to future periods. These political costs may be in the form of changes in regulation, changes in tax rates, and other changes in policy that may affect the company (Watts and Zimmerman, 1986). This hypothesis is in line with the reason why management chooses accounting policies to minimize tax. Tax is a form of political cost imposed on the company that reduces company earnings. For that reason, managers always act opportunistically in choosing accounting policies that will lower corporate tax (tax avoidance).

This research consists of six parts. The first part contains an introduction that consists of research phenomena, research problems, research objectives, differences in this study with previous research, and the selection of variables used in testing this study. The second part contains the development of hypotheses built in this study. The third part contains the research methodology, including the sampling conducted in this study and the proxy used to measure each variable in this study as well as the research model. The fourth part is the analysis and discussion that explains the results of this study both in statistical tests and reviews of research results. The fifth part is the conclusion which is a summary of the discussion based on the research objectives. The sixth part is the limitations and implications of both the practical implications and the implications for further research.

\section{HYPOTHESIS DEVELOPMENT}

According to agency theory, managers diversify the company for their benefit. These benefits may include higher pay to manage a diversified company (compared to managing a stand-alone company). Also, the fact that managing a diversified company increases the manager's prospect of future employment, as managing a diversified company, is seen as more prestigious than managing a stand-alone company. Many studies on corporate diversification are mainly about factors that determine diversification discount. Few, however, touches on the relationship between corporate diversification and tax avoidance activities. Recent research on the relationship of corporate diversification to tax avoidance activities is conducted by Zheng (2017). The study found that corporate diversification is negatively associated with tax avoidance. It was hypothesized that diversified companies engage less in tax avoidance because of the inherently poor corporate governance. Because of the ownership structure, the manager and owner's interests are not adequately aligned. Hence managers are not aggressive in pursuing tax avoidance to minimize costs. In the end, however, Zheng (2017) admitted that although corporate governance (through ownership structure) plays an essential role in tax avoidance activities, it does not have the extra power to explain the low levels of tax avoidance activities specifically in diversified companies. In Indonesia, research has shown that some mechanism of corporate governance is not sufficient according to their function (Puspita \& Harto, 2014).

The previous study conducted by Ushijima (2015) found that diversification discount in diversified companies can be attributed to the form of structure that diversified companies have. The structure of diversified companies could also explain their tax avoidance activities which tend to have a complex organizational structure. It is relatively harder to audit than a company with one segment. It requires extra effort by auditors to audit a more complexstructured company, as seen by higher fees paid to auditors in Bentley-Goode, Omer \& Sharp (2013). It provides a window of opportunity for managers to lower costs through tax avoidance activities. Although a previous study on the relation of company diversification on tax avoidance has shown that corporate diversification is neg- 
atively associated with tax avoidance (Zheng, 2017), it is still firmly believed, at least in Indonesia, that corporate diversification has a positive effect on the company's tax avoidance activities based on the company's complex structure. Companies that have considerable diversification cause complexity in their operations, resulting in audits of the financial statements of this type of company are also increasingly complex. Therefore, the expenses borne by the company are also significant. As a result, the company will minimize the costs that can be avoided, including tax expenses. Thus, the hypothesis in this study is as follows:

H1: Corporate diversification is positively associated with tax avoidance.

Information on the cost and benefits of having a strong customer base is information that is available firsthand to company managers (agents). Information asymmetry can be reduced by requiring more disclosure about the level of customer concentration and the relationship of the company with its customers. The decision to have a more concentrated customer by a company is based on its cost and benefit of having a close customer-supplier relationship. The benefit of having a small number of customers is customer loyalty, reduced costs, and higher performance. However, some costs need to be considered: the risk of higher buying power from major customers and other risks.

Previous research on customer concentration uncovers evidence that higher customer concentration may lead to liquidity problems and cash flow risks on the fear that those major customers may experience financial distress or decide to switch to other products or vendors. When one of the major customers have problems, it could punch a sizable hole in company revenue figures (Campello \& Gao, 2017; Dhaliwa, Judd, Serfling \& Shaikh, 2016). Another research by Itzkowitz (2013) argued that with more concentrated customers, the company would have to invest in costly relationship-specific assets. These assets may range in the form of lower leverage, more cash, or special equipment that sig- nals the supplier's commitment to building a strong relationship with the customer. Lastly, Gosman \& Kohlbeck (2009) confirmed the existence of buying power for major customers of a concentratedcustomer company. Again, this buying power gives customers the advantage that could adversely affect the performance of the suppliers.

Because of those reasons, companies with a strong customer base have incentives to hold more cash and manage earnings upward. Huang, Lobo, Wang \& Xie (2016) argued that companies with concentrated customers might turn to engage in tax avoidance activities to achieve those goals. Tax avoidance activities can free company cash by reducing the amount of tax paid to the government. At the same time, because income tax is a form of cost to the company, reducing it would mean cost-cutting that could improve profitability. As a result, companies that have a high concentration of customers tend to save expenses incurred, including the tax expenses that must be borne by the company every year. Therefore, the hypothesis in this study is as follows:

H2: Customer concentration is positively associated with tax avoidance

\section{RESEARCH METHODS}

This research employs a quantitative method. The data used for this study is secondary data. The population of data for this research is the financial data for the period of 2015 to 2017. The period (2015 to 2017) is selected to coincide with the enactment of PSAK 46 (2014 revision) which require firms to separate tax that is imposed on a measure of pretax income (income tax expense) and tax that is imposed on measures other than pretax income (final tax expense). The separation is crucial to measure tax avoidance in this research. In this study, companies are removed from a selection according to predetermined criteria. First, companies that went public after January 1, 2015. Second, companies that are categorized as financial companies according to IDX classification (banks, financial institutions, insurance) are excluded from the sample because the finance com- 
panies have inherently different reporting formats than those of other companies. Third, companies with incomplete data. Some companies were found to not have a complete financial statement data either in one or many financial years. These companies are removed from the sample altogether. Fourth, companies with negative pretax income because those can obscure the tax avoidance measurement.

The dependent variable in this research is tax avoidance. There are many measures of tax avoidance, from effective tax rate based measures (ETR, Annual ETR, Long-Run ETR), book-tax-difference based measures (BTD, Discretionary BTD, Discretionary Permanent BTD), unrecognized tax benefits, Henry \& Sansing's (HS) measure, and tax shelters. Each measure has its advantages and disadvantages. This research uses Discretionary Permanent BTD (DTAX), which was first introduced by (Frank, Lynch \& Rego, 2009). This measure of tax avoidance is based on a book-tax-difference measure. By controlling for nondiscretionary items of the permanent difference between book income and taxable income, this measure of tax avoidance captures the non-conforming tax avoidance.

The original equation from Frank et al. (2009) is adjusted by Rachmawati and Martani (2014), as presented in equation (1) to conform to the Indonesian context. In the equation, the permanent difference is controlled for goodwill and other intangible assets, change in loss carryforwards, and the non-discretionary permanent difference that persist through time.

$$
\begin{aligned}
\text { PERMDIFF }_{\mathrm{it}}= & \alpha_{0}+\beta_{1} \text { INTANG }_{\mathrm{it}}+\beta_{2} \Delta \mathrm{NOL}_{\mathrm{it}}+ \\
& \beta_{3} \text { LAGPERM }_{\mathrm{it}}+\varepsilon_{\mathrm{it}} \ldots \ldots \ldots \ldots .(1)
\end{aligned}
$$

Where:

$$
\begin{aligned}
& \text { PERMDIFF }_{\text {it }} \text { : Total BTD less temporary BTD } \\
& \text { for firm } \mathrm{i} \text { in year } \mathrm{t} \text { : }\left(\mathrm{BI}_{\mathrm{it}}-\right. \\
& \left.\left(\mathrm{CTE}_{\mathrm{it}} / \mathrm{STR}_{\mathrm{it}}\right)\right]-\left(\mathrm{DTE}_{\mathrm{it}} / \mathrm{STR}_{\mathrm{it}}\right) \\
& \mathrm{BI}_{\mathrm{it}} \quad \text { : Pretax income for firm } \mathrm{i} \text { in } \\
& \text { year } \mathrm{t} \\
& \mathrm{CTE}_{\mathrm{it}} \quad \text { : Current tax expense for firm i } \\
& \text { in year } t \\
& \text { DTE }_{\text {it }} \quad \text { : Deferred tax expense for firm } \\
& \mathrm{i} \text { in year } \mathrm{t} \\
& \text { STR }_{\mathrm{it}} \quad \text { : The statutory tax rate for firm } \\
& \mathrm{i} \text { in year } \mathrm{t}
\end{aligned}
$$

INTANG $_{\text {it }}$ : Goodwill and other intangible assets for firm $i$ in year $t$

$\Delta \mathrm{NOL}_{\mathrm{it}} \quad$ : Change in net operating loss for firm $i$ in year $t$

LAGPERM $_{\text {it }}$ : One-year lagged PERMDIFF for firm $\mathrm{i}$ in year $\mathrm{t}$

$\varepsilon_{\text {it }} \quad:$ The permanent discretionary difference for firm i in year $t$

This research, however, further adjusts the equation from Rachmawati \& Martani (2014) as presented in equation (2) to control for final tax. The final tax is regulated by law for specific industries so that companies cannot freely choose whether to apply the final tax. On the other hand, companies in those specific industries must accept and comply with the final tax policy. Final tax is a non-discretionary item that must also be controlled for when determining permanent discretionary difference. Thus, this study employs the equation to adjust the previous proxy (Rachmawati \& Martani, 2014), is as follows:

$$
\begin{aligned}
\text { PERMDIFF }_{\mathrm{it}}= & \alpha_{0}+\beta_{1} \text { INTANG }_{\mathrm{it}}+\beta_{2} \text { NNOL }_{\mathrm{it}}+ \\
& \left.\beta_{3} \text { LAGPERM }_{\mathrm{it}}+\beta_{3} \text { FINAL }_{\mathrm{it}}+\varepsilon_{\mathrm{it}} \ldots{ }^{2}\right)
\end{aligned}
$$

Where:

FINAL $_{\text {it }}$ : Final tax for firm i in year $\mathrm{t}$

Furthermore, the independent varia-

bles in this study are corporate diversification and customer concentration. Zheng (2017) used two dummy variables, D and $\mathrm{M}$, to account for corporate diversification. $\mathrm{D}$ takes the value of 1 if the company has more than one segment and 1 if the company has only one segment over the sample period. M takes the value of 1 if the company has multiple segments in a year and 0 otherwise. However, this measure of corporate diversification fails to capture the degree of diversification in a company.

This research uses a measure of corporate diversification based on $\mathrm{Gu}$, Wang, Yao \& Zhang (2018) which uses a measure based on the entropy index:

$$
\operatorname{DIVERSE}_{\mathrm{it}}=\sum_{\mathrm{i}=0}^{\mathrm{n}} \mathrm{P}_{\mathrm{it}} \operatorname{In}\left(1 / \mathrm{P}_{\mathrm{it}}\right)
$$

Where:

EI : Entropy Index

$P_{i}$ : Percentage of Revenue from Segment i

$\mathrm{n}$ : The number of segments

This measure of corporate diversification can capture the degree of diversifi- 
cation instead of just whether a company is diversified or not. It accounts for total sales from each segment to determine the degree of diversification in a company at a given year.

Furthermore, the proxy of customer concentration is based on Huang et al. (2017). It measures the ratio of sales to significant customers over total company sales. Sales to significant customers are sales made to the company's biggest customer. The company's biggest customers are those who purchase from the company accounts for $10 \%$ or higher from total company sales.

This research uses three controlled variables that have been proven to affect tax avoidance in previous studies: size,

$$
\mathrm{CONS}_{\mathrm{it}}=\frac{\text { Sales to Major Customers }}{\mathrm{it}}
$$

profitability, and leverage of the company (Darmawan \& Sukartha, 2014; Arianandini \& Ramantha, 2018; Lestari \& Putri, 2017; Dewi \& Noviari, 2017); Lionita \& Kusbandiyah, 2017). Profitability is measured using the return on asset (ROA). Company size uses the natural logarithm of a total company asset, while leverage is measured by the ratio of total company liabilities to total company assets.

$$
\begin{aligned}
& \mathrm{ROA}_{\mathrm{it}}=\frac{\text { Net Income }_{\mathrm{it}}}{\text { Total Assets }_{\mathrm{it}}} \\
& \mathrm{SIZE}_{\mathrm{it}}=\operatorname{In}(\text { Total Assets } \\
& \mathrm{it}
\end{aligned}
$$

LEVERAGE $_{\text {it }}=\frac{\text { Total Liabilities }_{\text {it }}}{\text { Total Assets }_{\text {it }}}$

Based on the explanation above, the research model in this study, as follows: $\mathrm{TAV}_{\mathrm{it}}=\beta_{0}+\beta_{1}$ DIVERSE $_{\mathrm{it}}+\beta_{2}$ CUSTOMER $_{\mathrm{it}}+\beta_{3}$ SIZE $_{\text {it }}$

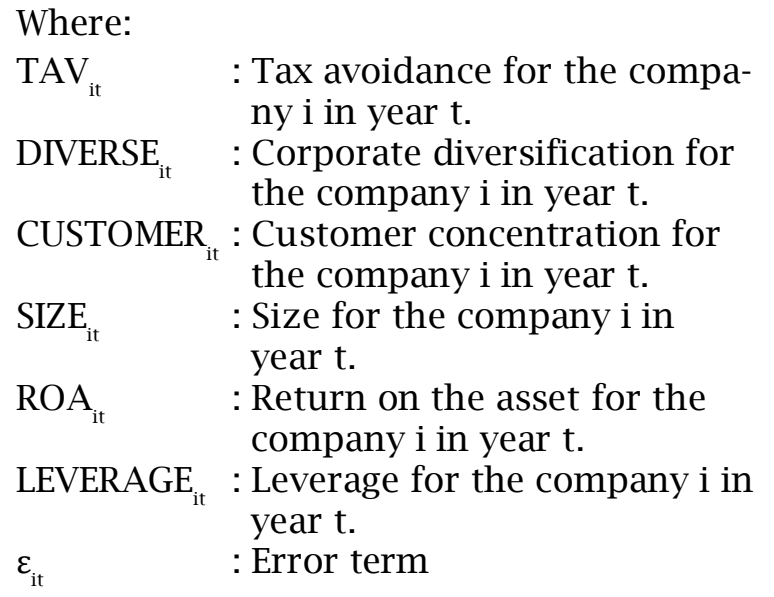

\section{ANALYSIS AND DISCUSSION}

Based on purposive sampling was conducted, this study obtains 161 sampled companies from 2015 to 2017 (3 years). Thus, the total number of observations is 483 firmyear. Regarding the IDX industry classification, the sampled companies can be clustered according to their industry classification. The highest number of companies sampled comes from Trade, Service and Investment industry, while the lowest number of companies come from the Agriculture industry.

The descriptive statistical analysis in this study is described by using the mean, maximum, minimum, and standard deviation (Std. Dev.). The summary of the results of descriptive statistics on the variables data in this study presented in Table 1.

Furthermore, the results of regression model selection tests (Chow test, Lagrange multiplier test, Hausman test) suggest that the most appropriate regression model in this research is a fixed-effect model (FEM). Based on the results of the normality test showed that the equation residuals in this study are not normally distributed. However, according to Baltagi (2005), the use of panel data can violate the

Table 1.

Descriptive Statistics

\begin{tabular}{lcccccc}
\hline & TAV & DIVERSE & CONS & SIZE & ROA & LEVERAGE \\
\hline Mean & $1.08 \mathrm{E}-17$ & 0.5558 & 0.1958 & 28.717 & 0.0717 & 0.4372 \\
Median & -0.0009 & 0.6146 & 0.0000 & 28.689 & 0.0524 & 0.4329 \\
Maximum & 0.3371 & 1.5158 & 1.0000 & 33.198 & 0.5267 & 0.9475 \\
Minimum & -0.4471 & 0.0000 & 0.0000 & 24.286 & -0.0971 & 0.0076 \\
Std. Dev. & 0.0455 & 0.4257 & 0.2875 & 1.7072 & 0.0766 & 0.1815 \\
Observations & 483 & 483 & 483 & 483 & 483 & 483 \\
\hline
\end{tabular}


normality test. Meanwhile, the initial data experiences heteroscedasticity, but the data can be overcome by doing GLS Weight (Widardjono, 2013), so the data becomes homoscedasticity. The multicollinearity test does not indicate that the variables do not correlate with each other because the independent variable has a correlation coefficient <0.80 (Ghozali, 2013). Panel data and regression models used are fixed-effect models; the autocorrelation test can be ignored, as explained by Nachrowi \& Usman (2006). Table 2 show the result of equation model regression.

\section{Discussion of the association between corporate diversification with tax avoid- ance}

Corporate diversification is positively related to tax avoidance. Business diversification is about building new products, exploring new markets, and taking new risks (Craig, 2015). Business diversification is represented by the number of business segments a business has and the number of sales in each segment relative to the others. The more segment a business has, the more diversified it is. However, when two businesses have the same number of segments, the more spread out the firm sales are generated from each segment, the more diversified it is compared to those that are generated more from one segment relative to other segments in the business. Hence, diversification is measured using the entropy index to account for the relative sales generated by each segment in a business.

According to agency theory, managers tend to protect their self-interest. One motivation why managers diversify the company is to maximize his/her benefits. There is more prestige in managing a big diversified company than a stand-alone company. This prestige can increase the prospect of hiring for managers because of the experience in managing a big diversified company. Future pay may also increase as a result. For the company itself, previous research found that diversifying can change the organizational structure to be more complicated. This complexity can affect the audit of the company by external auditors. Auditors would have to expend extra effort to audit the complex business structure. Auditing, a diversified company, is relatively harder than a stand-alone company, as shown by the higher audit fee of a diversified company compared to a standalone company. This condition is an opportunity for the company to cut costs by engaging in more tax avoidance activities. As a result, the more diversified the company is, the more likely that it engages in tax avoidance activities. Through statistical testing, the result of this research supports the hypothesis that managers use the opportunity provided by the intricate structure in the diversified company to mask its tax avoidance activities.

The result of this research, however, contradicts a previous study on the relationship of corporate diversification and tax avoidance by Zheng (2017), who found that diversified companies engage less in tax avoidance and that tax effects may not be considered as first-order importance in corporate diversification. Zheng (2017) uses two dummy variables to account for di-

Table 2.

Equation Model Regression Test Results

\begin{tabular}{lccccc}
\hline \multicolumn{1}{c}{ Variable } & Coef. & Std. Error & t-Statistic & Prob. & \\
\hline C & -0.0812 & 0.0205 & -3.9511 & 0.000 & $* * * *)$ \\
DIVERSE & 0.0159 & 0.0056 & 2.8352 & 0.005 & $* * * *)$ \\
CONS & 0.0091 & 0.0034 & 2.6804 & 0.007 & $* * *)$ \\
SIZE & 0.0007 & 0.0006 & 1.1763 & 0.240 & \\
ROA & 0.5846 & 0.0289 & 20.205 & 0.000 & $* * * *)$ \\
LEVERAGE & 0.0133 & 0.0112 & 1.1828 & 0.237 & \\
R-squared & & 0.858724 & & & \\
Adjusted R-squared & & 0.785189 & & & \\
F-statistic & & 11.67777 & & & \\
Prob (F-statistic) & & 0.000000 & & &
\end{tabular}

$* * *)$ significant at $1 \%$ 
versification. The first dummy variable takes the value of 1 if a company is diversified (has more than one segment in at least one year during the sample period) and 0 if it is a stand-alone company (has only one segment over the sample period). The second dummy variable captures a firm incremental tax avoidance practice while having multiple segments. It takes the value of 1 if a firm has multiple segments during the year and 0 otherwise. This research, however, uses only one variable to account for diversification (DIVERSE). By using the entropy index measurement, corporate diversification can be differentiated and captured by the number of segments a company has and by the number of sales generated by each segment. Hence, the value is not a dummy variable.

Contrary to the conclusion by Zhang (2017), that tax effect is not first-order importance in corporate diversification. This research shows that tax effects are essential in corporate diversification in Indonesia. Zhang (2017) argued that corporate governance might play a role in the relation of corporate diversification and tax avoidance is proven to be not powerful enough to explain the said relation. Corporate governance in Indonesia is found to be not as effective (Puspita \& Harto, 2014). Corporate diversification is related to tax avoidance because of the complexity of organizational structure. Diversified companies are found to have a complex organizational structure. The complexity of which affects the ability of auditors to audit the company. It presents an opportunity for managers to engage in corporate tax avoidance. Because tax is considered as a cost to the company based on the political-cost hypothesis, managers are further encouraged to engage in tax avoidance practice.

\section{Discussion of the association between customer concentration with tax avoid- ance}

Customer concentration is positively related to tax avoidance. Customer concentration measures how a company's total revenue is distributed among its customer base. A company with a small number of large customers is said to be highly concen- trated. On the other hand, a company with a large number of evenly distributed customers is said not to be concentrated (diversified). Even if a company has a large number of customers, if the majority of sales only go to one or two customers, then the customer base is also said to be highly concentrated.

This research proved that customer concentration in a company is positively related to tax avoidance. The more concentrated the customer base of a company is, the more likely it will engage in tax avoidance practices. There are three reasons why companies with a strong customer base would likely engage in tax avoidance activities. First, companies that have a concentrated customer is exposed to cash flow risk originating from its major customers. When one of those significant customer experience financial distress or decides to switch to other vendors, it will cause a significant loss to the supplier's source of revenue. Second, companies with a strong customer base must invest in relationshipspecific assets as a commitment to its major customers. These commitment-specific assets may range from holding more cash, reducing company leverage, to investing in specific assets that cater to the specific needs of those significant customers. These commitments are done to keep customers from switching (increase customer loyalty). Lastly, significant customers of the concentrated-customer company have buying powers. This buying power is used by major customers to lower the purchase price of goods and services from the suppliers, extend credit periods, and purchase in small batches at irregular intervals. All this at a cost to the concentrated-customer company as the supplier.

These three reasons (cash flow risk, investment in relationship-specific assets, and the existence of customer buying power) encourage and incentivize companies with a strong customer base to hold more cash and manage earnings upward. Tax, based on the political cost hypothesis, represent a cost to the company. By lowering or avoiding tax, companies could limit cash outflow and lower costs that translate to better company profitability and perfor- 
mance. Thus, companies that have a strong customer base are more likely to engage in tax avoidance activities.

This result corresponds with previous research conducted by Huang et al. (2016). Huang et al. (2016) use a sample of non-financial service companies in the US. Companies with a strong customer base are exposed to cash flow risk, must invest in relationship-specific assets, and faces significant customers that have buying powers. All this increases the need for cash and also increases the cost to the company as the supplier. Tax avoidance is known to reduce the amount of cash outflow and at the same time, cut costs to the company. It incentivizes managers in a company with a concentrated customer base to engage in tax avoidance to decrease cash outflow and increase after-tax profits.

This research also somewhat conforms with the research by Cen et al. (2017), which states that a more concentrated customer base will likely induce a closer customer-supplier relationship. This close relationship between a supplier and its customers may facilitate the engagement of tax avoidance through the supply chain. Thus, besides it being an incentive to engage in tax avoidance, a more concentrated customer base might also be a possible channel in which the company mitigates those problems attributed to tax avoidance by building strong relationships with those few customers and working together to minimize corporate tax.

\section{CONCLUSION}

The hypothesis examination suggests that corporate diversification is positively associated with tax avoidance. Corporate diversification could change the organizational structure to be more complicated. This complexity can affect the audit of the company by external auditors. Auditors would have to expend extra effort to audit the complex business structure. Auditing, a diversified company, is relatively harder than a stand-alone company, as shown by the higher audit fee of a diversified company compared to a stand-alone company. This condition is an opportunity for the company to cut costs by engaging in more tax avoidance activities. As a result, the more diversified the company is, the more likely that it engages in tax avoidance activities.

Furthermore, customer concentration is positively associated with tax avoidance. A more concentrated customer also has inherent uncertainties that might risk the company. When a large customer decides to switch to another supplier, there is a chance the company might lose a significant source of its revenue. The risk is more pronounced when the cost of switching is low for the customers. Hence companies engage in tax avoidance to mitigate the increased risk. In addition to that, with a small number of concentrated customers, companies may build a close relationship with those customers that could facilitate the act of reducing corporate tax. It is a solution where both parties can benefit.

\section{LIMITATIONS AND IMPLICATIONS}

This study still has limitations. This study only uses a sample of 161 companies in three years. A much bigger sample with more than 161 companies with a period of more than three years would reduce statistical error. This research also uses a measure of tax avoidance that has never been applied in previous studies. Future research may extend the period of research object to add more observations and capture more comprehensively the relation of corporate diversification, customer concentration, and the related-party transaction to tax avoidance. Also, future research may use companies in the finance industry.

Furthermore, the proxy of tax avoidance used in this research is a modified abnormal book-tax difference by Rachmawati \& Martani (2014) to proxy for discretionary permanent book-tax difference cause by the final tax. Future research may improve the proxy to account for the final tax. For example, using net income attributed to the final tax rather than the final tax itself. Otherwise, other proxies for tax avoidance may be used in future research, such as ETRs or BTDs.

Company diversification and customer concentration are reasonable indications of whether a company is engaging in tax 
avoidance or not. Because the ratio of tax account-representative and tax auditor to the number of taxpayers is small, it is quite hard to determine the optimum choice of which taxpayer to scrutinize and supervise (by account representative) and which to audit (by auditors). To solve that problem, Indonesia Tax Authority has started to implement risk-based audits. Risk-based audits help in determining which taxpayers need to be audited based on the risk of taxpayer's noncompliance. Precise third-party data and evidence (such as from banks or AEOI) may rank high to determine the right taxpayer to audit. However, for further input, corporate diversification, customer concentration, and related-party transactions may be considered by tax-auditors as criteria in risk-based audits or even supervision by account-representatives.

More disclosure requirements, especially for the disclosure of corporate tax. Companies should disclose more on final tax and other special tax incentives other than the normal tax rate. The company's disclosure on the amount of net operating income (revenue fewer expenses) that is subjected to final tax or other tax incentives that are not considered when calculating income tax payable should be required. Another disclosure that should be made mandatory is transactions to companies which are subject to final tax or other special tax incentives. By requiring the disclosure, investors and researchers might find out whether or not companies in Indonesia tend to shift income to companies which are subject to final tax or other special tax incentives. The accounting-standard setting body should also consider requiring separate financial statements and also its disclosure (notes to the separate financial statements) for individual companies, not only as a group. It is conducted so that there is an equal comparison between tax reporting and financial reporting to analyze corporate tax (especially tax avoidance).

Based on this research, investors have a more comprehensive look at a company to determine whether or not to invest in a company based on company risk and the investor's risk profile. Investors may look at company diversification, customer concentration, and related-party transaction on more information about its inherent risk and how it relates to efforts by the company to lower corporate tax. These actions or characteristics of the company may be matched by investors' risk appetite to determine whether or not to invest in a company.

\section{REFERENCES}

Alm, J. (2012). Measuring, explaining, and controlling tax evasion: lessons from theory, experiments, and field studies. International Tax and Public Finance, 19(1), 54-77.

Arianandini, P.W., \& Ramantha, I.W. (2018). Pengaruh profitabilitas, leverage, dan kepemilikan institusional pada tax avoidance. E-Jurnal Akuntansi Universitas Udayana, 22(3), 2088-2116.

Arieftiara, D., Utama, S., Wardhani, R., \& Ning, R. (2015). Analisis pengaruh strategi bisnis terhadap penghindaran pajak, bukti empiris di Indonesia. Simposium Akuntansi $\mathrm{Na}$ sional XVIII, 18(1), 1-27.

Azizah, N., \& Kusmuriyanto (2016). The effect of related party transaction, leverage, commissioners, and directors compensation on tax aggressiveness. Accounting Analysis Journal, 5 (4), 307-16.

Baltagi, B. H. (2005). Econometric analysis of panel data, third edition. England: John Wiley \& Sons.

Bentley-Goode, K.A., Omer, T.C., \& Sharp, N.Y. (2013). Business strategy, financial reporting irregularities, and audit effort. Contemporary Accounting Research, 30(2), 780-817.

Campello, M., \& Gao, J. (2017). Customer concentration and loan contract terms. Journal of Financial Economics, 123(1), 108-36.

Cen, L., Maydew, E. L., Zhang, L., \& Zuo, L. (2017). Customer - supplier relationships and corporate tax avoidance. Journal of Financial Economics, 123 (2): 377-94.

Cobham, A., \& Janský, P. (2018). Global distribution of revenue loss from corporate tax avoidance: re-estimation and country results. Journal of International Development, 30(2), 206-32.

Craig, W. (2015). Business diversification: The risk and the reward. https:// www.forbes.com/sites/ williamcraig/2015/04/24/business- 
diversification-the-risk-and-thereward/\#35aa36087d09

Darmawan, I.G.H., \& Sukartha, I.M. (2014). Pengaruh penerapan corporate governance, leverage, return on assets, dan ukuran perusahaan pada penghindaran pajak. E-Jurnal Akuntansi Universitas Udayana, 9(1), 143-61.

Dewi, N.L.P., \& Noviari, N. (2017). Pengaruh ukuran perusahaan, leverage, profitabilitas dan corporate social responsibility terhadap penghindar pajak (tax avoidance). E-Jurnal Akuntansi Universitas Udayana, 21(1), 830-59.

Dhaliwal, D., Judd, J.S., Serfling, M., \& Shaikh, S. (2016). Customer concentration risk and the cost of equity capital. Journal of Accounting and Economics, 61(1), 23-48.

Ferdiawan, Y., \& Firmansyah, A. (2017). Pengaruh political connection, foreign activity, dan real earnings management terhadap tax avoidance. Jurnal Riset Akuntansi Dan Keuangan, 5(3), 1601-1624

Frank, M.M. Lynch, L.J., \& Rego, S.O. (2009). Tax reporting aggressiveness and its relation to aggressive financial reporting. The Accounting Review, 84 (2), 467-96.

Ghozali, I. (2013). Aplikasi analisis multivariate dengan program IBM SPSS 21 , edisi 7. Semarang: Badan Penerbit Universitas Diponegoro.

Gosman, M.L, \& Kohlbeck, M.J. (2009). Effects of the existence and identity of major customers on supplier profitability: is Wal-mart different? Journal of Management Accounting Research, 21(1), 179-201.

Gu, L., Wang, Y., Yao, W., \& Zhang, Y. (2018). Stock liquidity and corporate diversification: Evidence from china's split share structure reform. Journal of Empirical Finance.

Guenther, D.A., Matsunaga, S.R., \& Williams, B.M. (2017). Is tax avoidance related to firm risk? The Accounting Review, 92(1), 115-36.

Hanlon, M., \& Heitzman, S. (2010). A review of tax research. Journal of Accounting and Economics, 50(2-3), 127-78.

History.com Editors. (2009). Boston tea party. https://www.history.com/topics/ american-revolution/boston-teaparty.

Huang, H., Lobo, G.L, Wang, C., \& Xie, H. (2016). Customer concentration and corporate tax avoidance. Journal of Banking and Finance, 72, 184-200.
Huang, H, Sun, L., Zhang, J. (2017). Environmental uncertainty and tax avoidance. Advances in Taxation, 83-124.

Itzkowitz, J. (2013). Customers and cash: how relationships affect suppliers' cash holdings. Journal of Corporate Finance, 19, 159-80.

Kirchler, E. (2007). The economic psychology of tax behaviour. New York: Cambridge University Press.

Kusuma, A.C., \& Firmansyah, A. (2018). Manajemen laba, corporate governance, kualitas auditor eksternal dan agresivitas pajak. Jurnal Tekun, 8(1), 108-123.

Lestari, G.A.W, \& Putri, I.G.A.M.A.D. (2017). Pengaruh corporate governance, koneksi politik, dan leverage terhadap penghindaran pajak. E-Jurnal Akuntansi Universitas Udayana, 18 (3), 2028-54.

Lionita, A., \& Kusbandiyah, A. (2017). Pengaruh corporate social responsibility, profitability, leverage, dan komisaris independen terhadap praktik penghindaran pajak pada perusahaan yang terdaftar di BEI. Kompartemen: Jurnal Ilmiah Akuntansi, XV(1), 1-11.

Mankiw, N.G. (2012). Principles of Economics Sixth Edition. Sixth. Mason: SouthWestern Cengage Learning.

Marvin, M.J. (2019). Avoiding higher customer concentration. https:// gatewaycfs.com/bff/avoiding-highcustomer-concentration.

Nachrowi, D.N., \& Usman, H. (2006). Pendekatan populer dan praktis ekonometrika untuk analisis ekonomi dan keuangan. Fakultas Ekonomi Universitas Indonesia.

Oktavia, Kristanto, S.B., Subagyo, \& Kurniawati, H. (2012). Transaksi hubungan istimewa dan pengaruhnya. Jurnal Akuntansi, 12, 701-16.

Puspita, S.R., \& Harto, P. (2014). Pengaruh tata kelola perusahaan terhadap penghindaran pajak. Diponegoro Journal of Accounting, 3(2), 1-13.

Rachmawati, N.A. \& Martani, D. (2014). Pengaruh large positive abnormal book-tax differences terhadap persistensi laba. Jurnal Akuntansi dan Keuangan Indonesia, 11(2), 120-37.

Reuters. (2017). https://www.reuters.com/ article/us-indonesia-taxation-finmin/ indonesia-finance-minister-says-totackle-tax-avoidance-by-mncsidUSKBN19X125. accessed on May $12^{\text {th }}, 2019$.

Sari, D.K., Utama, S., Rossieta, H. (2017). Tax avoidance, related party transac- 
JURNAL AKUNTANSI DAN BISNIS Vol. 19, No. 2, Agustus 2019: 196-207

tions, corporate governance, and the corporate cash dividend policy. Journal of Indonesian Economy and Business Volume, 32(3), 190 - 208.

Ushijima, T. (2015). Diversification, organization, and value of the firm. Financial Management, 467-99.

Wardani, D.K., \& Khoiriyah, D. (2018). Pengaruh strategi bisnis dan karakteristik perusahaan terhadap penghindaran pajak. Akuntansi Dewantara, 2(1), 25-36.

Watts, R.L., \& Zimmerman, J.L. (1986). Positive accounting theory. Englewood Cliffs, N.J: Prentice-Hall.
Widarjono, A. (2013). Ekonometrika pengantar dan aplikasinya. Jakarta: Ekonosia.

Wijayanti, A., Wijayanti, A., \& Chomsatu, Y. (2017). Pengaruh karakteristik perusahaan, GCG, dan CSR terhadap penghindaran pajak. Journal of Economic and Economic Education, 5(2), 113-27.

Zheng, S. (2017). Can corporate diversification induce more tax avoidance practices? Evidence from the US Companies. Journal of Multinational Financial Management. 